\title{
Habitat factors differentiating the occurrence of Ostracoda (Crustacea) in the floodplain of a small lowland River Krapiel (N-W Poland)
}

\author{
Agnieszka Szlauer-Łukaszewska ${ }^{1,{ }^{*}}$ and Vladimir Pešić ${ }^{2}$ \\ ${ }^{1}$ Institute of Marine and Environmental Sciences, University of Szczecin, ul. A. Mickiewicza 16, 70-383 Szczecin, Poland \\ 2 Department of Biology, University of Montenegro, Cetinjski put b.b., 81000 Podgorica, Montenegro
}

Received: 15 January 2020 / Accepted: 31 March 2020

\begin{abstract}
We analysed the occurrence of ostracods in a small river, taking into account all the types of water bodies in the floodplain - these included helocrenes, oxbow lakes, and ponds, as well as the main river channel. The objective of the study was to investigate the variation in ostracod communities and identify those factors determining species distribution. The environmental factors considered were the type of water body, responsible for $17 \%$ of the variance, the physical and chemical water properties (29\%), and the biotic and abiotic factors associated with the substrate type (23\%). Among the factors associated with the substrate, sediment sorting, plant coverage and insolation were the most important. The ostracod fauna of the helocrenes differed from that of the other water bodies in the floodplain. In the water bodies of the Krapiel valley and in the main river channel, 33 ostracod species were recorded, of which 26 were found in the main river channel. Refugia in the floodplain were the main source of the diversity and abundance of ostracods in the main river channel. The mean density in the main river channel was very low, at $330 \mathrm{indiv} . \mathrm{m}^{-2}$, while in the water bodies of the floodplain it was the greatest, reaching up to 5568 indiv. $\mathrm{m}^{-2}$.
\end{abstract}

Keywords: Benthos / environmental conditions / substrate / species distribution

Résumé - Facteurs d'habitat différenciant la présence des Ostracodes (Crustacea) dans la plaine d'inondation de la petite rivière de plaine Krąiel (N-O Pologne). Nous avons analysé la présence des ostracodes dans une petite rivière, en tenant compte de tous les types de plans d'eau dans la plaine d'inondation; ceux-ci comprenaient des sources hélocrènes, des bras morts et des étangs, ainsi que le chenal principal de la rivière. L'objectif de l'étude était d'étudier la variation des communautés d'ostracodes et d'identifier les facteurs déterminant la distribution des espèces. Les facteurs environnementaux considérés étaient le type de masse d'eau, responsable de $17 \%$ de la variance, les propriétés physiques et chimiques de l'eau (29\%), et les facteurs biotiques et abiotiques associés au type de substrat (23\%). Parmi les facteurs associés au substrat, le tri des sédiments, la couverture végétale et l'ensoleillement étaient les plus importants. La faune ostracodienne des sources hélocrènes différait de celle des autres masses d'eau de la plaine d'inondation. Dans les masses d'eau de la vallée de la Krąpiel et dans le chenal principal de la rivière, 33 espèces d'ostracodes ont été enregistrées, dont 26 dans le chenal principal de la rivière. Les refuges dans la plaine d'inondation étaient la principale source de la diversité et de l'abondance des ostracodes dans le canal fluvial principal. La densité moyenne dans le canal fluvial principal était très faible, 330 indiv. $\mathrm{m}^{-2}$, tandis que dans les masses d'eau de la plaine d'inondation, elle était la plus élevée, atteignant jusqu'à 5568 indiv. $\mathrm{m}^{-2}$.

Mots-clés : benthos / conditions environnementales / substrat / répartition des espèces

\section{Introduction}

Freshwater ostracods are small, bivalved, benthic crustaceans, generally $0.3-5 \mathrm{~mm}$ long (Meisch, 2000). They are

\footnotetext{
${ }^{*}$ Corresponding author: aszlauer@gmail.com
}

present in almost all aquatic habitats, including lakes, canals, oxbow lakes, ponds, ditches, and rivers, but in mountain brooks they are restricted to calm areas and interstitial habitats. They usually live on the surface of the bottom sediments or burrow in them, but species with long natatory setae on their antennae can also swim (Meisch, 2000). In rivers, their densities are much greater in habitats with a slow current and 
more organic matter in the sediments than in typical lotic habitats (e.g. Szlauer-Łukaszewska, 2013, 2015a, 2015b). There have been very few studies on the distribution of ostracods along the whole length of a river valley, from the headwaters to the mouth of the river. Those studies known from the literature are limited to selected stretches of a particular river or valley (Scharf, 1988; Marmonier and Creuzé des Châtelliers, 1992; Creuzé des Châtelliers and Marmonier, 1993; Mezquita et al., 1999a, 1999b; Nagorskaya and de Jonge, 2002; Nagorskaya and Keyser, 2005; Kiss, 2006; Kiss and Schöll, 2009; Higuti et al., 2009, 2010; Scharf and Brunke, 2013; Szlauer-Łukaszewska, 2013, 2015a, 2015b). A very few studies have considered the other habitats of the river valley outside the main river channel: these include oxbow lakes (Scharf, 1988) or oxbow lakes and backwater canals (Kiss, 2006; Kiss and Schöll, 2009; Nagorskaya and de Jonge, 2002; Higuti et al., 2009, 2010). Studies on rivers have generally not taken into account springs situated in the valley, but these have been studied separately, without associating them with the river system (Roca and Baltanás, 1993; Mezquita et al., 1999c; Rosati et al., 2014; Zhai et al., 2015).

The aim of the study was to investigate the variation in ostracod communities and identify the factors determining species distribution along the entire valley of a small lowland river in the temperate zone, from the headwaters to the mouth of the river. On a spatial scale, we analysed the upstreamdownstream gradient of environmental variability and the variability of all the water bodies of the floodplain as integral components of the river valley and the processes taking place in it. The analysis took into account all the types of water

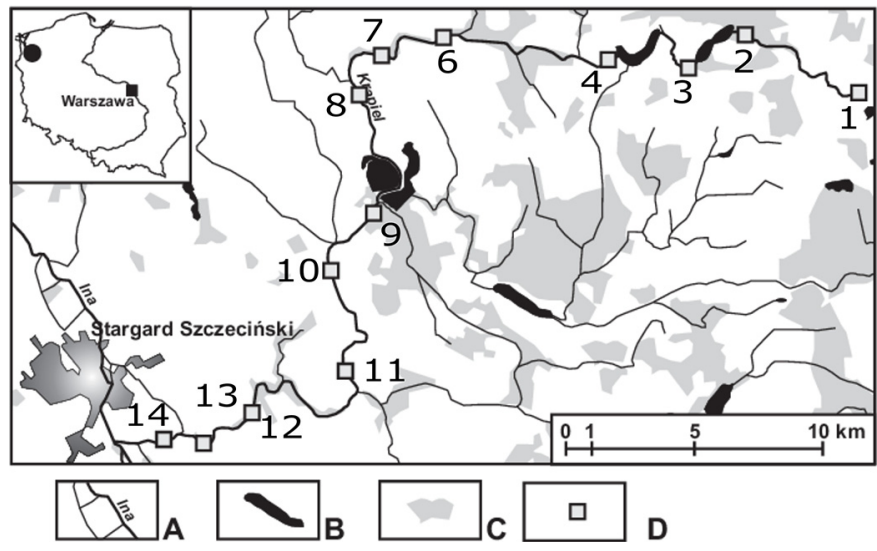

Fig. 1. Map of the River Krąpiel with sampling sites. A - rivers, B lakes, C - forests, D - sampling sites (1-14). bodies situated in the floodplain: the main river channel, helocrenes, oxbow lakes, and ponds.

\section{Material and methods}

\subsection{Methods of sampling and processing}

Samples were collected from the small lowland River Krapiel (in northwest Poland), which is $65 \mathrm{~km}$ in length, and has a catchment area of $596 \mathrm{~km}^{2}$. Its source is located at $96 \mathrm{~m}$ above sea level and the mouth at $21 \mathrm{~m}$ above sea level The width of the river valley ranges from $10 \mathrm{~m}$ to $400 \mathrm{~m}$. Most of the river flows in a postglacial channel. From Pęzino, it carries water through a moraine plateau area in a deep gorge valley. The initial stretch of the river has the character of a lowland loess or loamy stream, while in the lower reaches it is classified as a lowland gravel river. The river flows through agricultural areas for nearly its entire length. The valley is covered by deciduous forest (Stępień et al., 2015).

The fieldwork was conducted in May, August and October 2010. The research covered the entire length of the river, where 13 sampling sites were established (Fig. 1), distributed in such a way as to cover all habitat types, where possible. The following types of habitats were distinguished:

- the main river channel - including lotic habitats (riv lo) and lentic habitats (riv le)

- water bodies in the floodplain - oxbow lakes, ponds, backwaters (flo le) and springs (helocrenes - hel)

Table 1 shows the number of samples taken in each habitat type along the Krapiel valley. Helocrenes were the least common habitats in the river valley; only 7 were found that were large enough not to be destroyed by sampling (these were Sites 2, 3, 4, 7 and 12). We found 12 standing water bodies in the floodplain (flo le), at Sites 1, 4, 6, 7, 8, 9, 10, 12 and 14. Habitats from the main river channel were represented at each site.

Each sampling consisted of 10 energetic sweeps and covered an area of about $0.5 \mathrm{~m}^{2}$, so the samples can be considered semi-quantitative. In some months, due to a lack of water or very high water, no samples were collected from certain habitats. A total of 111 samples were collected in which the presence of ostracods was detected.

The following environmental parameters were determined for each sample: the physical and chemical parameters of the water, the sludge particle size, and the vegetation cover. The following water variables were determined: temperature, $\mathrm{pH}$, electrolytic conductivity, and dissolved oxygen content, which was examined using an Elmetron CX-401 multiparametric

Table 1. Number of samples, ostracod density, SD in particular habitat types in the Krapiel valley in different seasons. The abbreviations; riv lolotic habitats of the main river channel, riv le- lotic habitats of the main river channel, flo le- lentic habitas of the floodplain, hel- helocrenes.

\begin{tabular}{|c|c|c|c|c|c|c|c|c|c|c|c|c|c|}
\hline & \multicolumn{4}{|c|}{ May 2010} & \multicolumn{4}{|c|}{ August 2010} & \multicolumn{4}{|c|}{ October 2010} & \multirow[t]{2}{*}{ Sum } \\
\hline & riv lo & riv le & flo le & hel & riv lo & riv le & flo le & hel & riv lo & riv le & flo le & hel & \\
\hline \multirow{2}{*}{$\begin{array}{l}\text { number of samples density } \\
\text { indiv } \mathrm{m}^{-2}\end{array}$} & 17 & 8 & 9 & 7 & 17 & 12 & 6 & 1 & 17 & 10 & 6 & 1 & 111 \\
\hline & 229 & 537 & 99 & 193 & 13 & 159 & 1006 & 696 & 34 & 214 & 152 & 1303 & \\
\hline SD & 536 & 832 & 211 & 114 & 9 & 240 & 2043 & 0 & 46 & 210 & 241 & 0 & \\
\hline
\end{tabular}


sampling probe; $\mathrm{BOD}_{5}$ was determined by Winkler's method; water flow (velocity) was identified using a SonTek acoustic FlowTracker flowmeter; $\mathrm{NH}_{4}{ }^{+}, \mathrm{NO}_{3}{ }^{-}, \mathrm{PO}_{4}{ }^{3-}, \mathrm{Fe}^{2+} / \mathrm{Fe}^{3+}$, and carbonate hardness $\left[\mathrm{mg} \mathrm{l}^{-1}\right]$ with a Slandi LF300 photometer; turbidity with a Slandi LF 205 photometer; and insolation with a CEM DT-1309 light meter. The analysis of the bottom sediment included its granulometric composition and the content of organic and mineral matter. Calculations for granulometric analysis were made using the Krumbein phi scale, in which grain size (d) in $\mathrm{mm}$ is expressed in phi $(\phi)$ units, where:

$$
\phi=-\log _{2} \mathrm{~d}[\mathrm{~mm}] .
$$

Mean grain size (the graphic arithmetic mean) was calculated, i.e. the mean diameter, $M=(\phi 16+\phi 50+$ $\phi 84) / 3$, as well as grain-size sorting (through graphic standard deviation), and a measure of the dispersion of grain diameter values:

$$
W=[(\phi 84-\phi 16) / 4]+[(\phi 95-\phi 5) / 6.6] .
$$

Individual sediment samples were freeze-dried in a Christ Alpha 1-2 LD plus freeze dryer, and then the organic matter was removed from each sample by heating the sample in a Nabertherm furnace at $550^{\circ} \mathrm{C}$ to obtain a solid mass. In this manner, the percentages of mineral and organic matter were determined. 0 to 5 .

The degree of vegetation cover was specified on a scale of

\subsection{Data analysis}

For the statistical tests and data analysis we used STATISTICA ver. 10 INC StatSoft, according to the methods applied by Sokal and Rohlf (1995), and PAST ver. 2.17c (Hammer et al., 2001).

NPManova (Non-Parametric MANOVA) was performed between groups of ostracod samples from different types of river habitats in the main river channel and from the water bodies in the floodplain.

Diversity indices, i.e. the number of taxa $(\mathrm{S})$, the density, the dominance (D), the Shannon index $(\mathrm{H})$, and the Buzas and Gibson's evenness index $\left(\mathrm{e}^{\mathrm{H}} / \mathrm{s}\right)$, were calculated for different habitat types: lotic rivers (riv lo), lentic rivers (riv le), the lentic floodplain (flo le) and the helocrenes (hel). The dominance $(D)$ corresponds to 1 -Simpson index, and ranges from 0 to 1 :

$$
D=\sum_{i}\left(\frac{n_{i}}{n}\right)^{2}
$$

where $n_{i}$ is a number of individuals of taxon $i$. The KruskalWallis test was also performed between them for these diversity indices.

The relationship between Ostracoda species composition and habitat variables was analysed using the CANOCO v. 4.5 software package (ter Braak and Šmilauer, 2002). We used CCA (Canonical Correspondence Analysis) (ter Braak, 1986) to analyse the patterns of species distribution in relation to the environmental variables, having previously obtained the results of indirect DCA (Detrended Correspondence Analysis), which defined the structure of the data (Jongman et al., 1987). The species and environmental data were not transformed;
Table 2. Diversity indices for individual habitats of the Krapiel valley.

\begin{tabular}{lllll}
\hline & riv lo & riv le & flo le & hel \\
\hline Average number of taxa S & 3.47 & 5.37 & 3.40 & 6.56 \\
Total number of taxa & 27 & 27 & 18 & 20 \\
Total number of species & 21 & 22 & 14 & 16 \\
${\text { Density (indiv. } \mathrm{m}^{-2} \text { ) }}_{\text {Dominance D }}$ & 92 & 278 & 387 & 372 \\
Shannon H & 0.58 & 0.55 & 0.57 & 0.46 \\
Evenness $\mathrm{e}^{\wedge} \mathrm{H} / \mathrm{S}$ & 0.76 & 0.90 & 0.78 & 1.07 \\
\hline
\end{tabular}

species recorded fewer than 4 times were removed before analysis. The significance of the effect of each environmental variable on the diversity of species composition was determined using stepwise variable selection ( $\mathrm{p} \leq 0.05$ ). The Monte Carlo test was conducted with 499 permutations to identify the most significant variables. Variation in Ostracoda composition, explained by habitat type, substrate, and the physical and chemical variables included in the analysis, was expressed as a percentage - the ratio of the sum of all the canonical eigenvalues to the value of the total variance (total inertia). Variation in ostracod composition explained by individual variables was calculated from the ratio of Lambda A to the total variance (total inertia), expressed as a percentage. Spearman's rank correlation coefficient was used to identify correlations between densities of ostracod taxa and habitat type; chemical water variables and habitat type; and substrate variables and habitat type.

Cluster analysis was performed to determine the relationships between segments of the river on the basis of ostracod species composition in the river channel (via the Unweighted Pair Group Method with Arithmetic Mean - UPGMA, using correlation similarity).

\section{Results}

The NPManova performed for groups of samples from different river habitat types showed that the samples collected from lotic habitats in the river and from helocrenes differed significantly from the other groups of samples $(p<0.05)$. Significant differences were also found between the samples from lentic habitats in the main river channel and from ponds. Thus the samples were grouped as follows for further analysis: lotic river (riv lo), lentic river (riv le), lentic floodplain (flo le), and helocrenes (hel).

The Kruskal-Wallis test for diversity indices between habitat types showed significant differences for the number of taxa, mean density, and evenness index only between habitats: the lotic river, the lentic river and the helocrenes and between the helocrenes and the floodplain. No significant differences were found for the other indices tested.

The diversity index values for the habitats of the Krapiel valley are presented in Table 2. The habitats of the floodplain (fol le) and helocrenes (hel) had the greatest ostracod density, and the helocrenes also had the highest mean Shannon index and the lowest evenness index. Spearman's rank correlation revealed the occurrence of significant negative correlations between the lotic river (riv lo) and all other habitats; and 


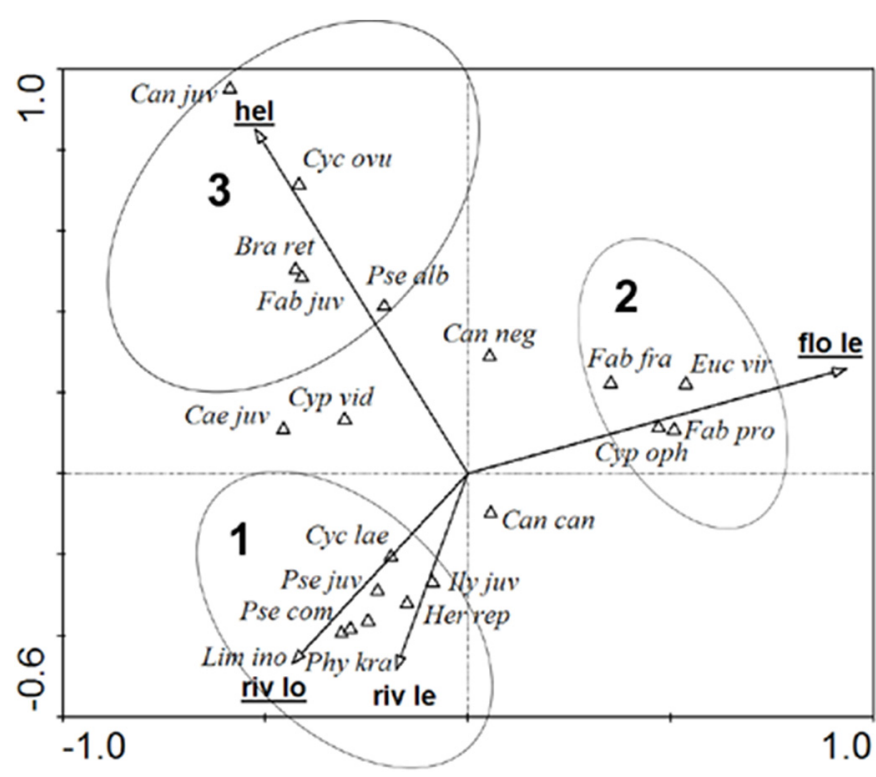

Fig. 2. The ordination diagram for ostracod species and habitat types on the first two CCA axes for samples from the Krapiel valley. For explanations of species abbreviations see Table 3. Statistically significant habitat variables are underlined.

otherwise between the floodplain (flo le) and all river habitats $(p<0.05 ; k\{-0.27 ;-0.56\})$.

The DCA analysis for ostracod samples from the River Krapiel revealed that the length of the gradient represented by the first ordination axis was $3.3 \mathrm{SD}$, so we conducted a direct ordination analysis of the CCA type to determine the relationships between species occurrence and substrate variables. The CCA showed that habitat types were responsible for $17 \%$ of the total variance in ostracod assemblages in the valley of the Krapiel. The stepwise selection of environmental variables in the multiple canonical analyses showed that flo le were responsible for $7.93 \%$ of the variance in ostracod assemblages, hel for $6.99 \%$, and riv lo for $2.15 \%$, while riv le did not significantly influence ostracod assemblages. The CCA diagram shows that only Candona candida, Neglecandona neglecta and Cypridopsis vidua, as eurytopic species, were not strongly related to any of the environmental vectors. Area 1 on the graph indicates species that are strongly related to lotic river habitats, area 2 indicates relationships with lentic habitats outside the river, and area 3 shows relationships with helocrenes (Fig. 2).

Spearman's rank correlation revealed numerous significant correlations between individual ostracod species and habitat types (Tab. 3). No species was found to be positively correlated with riv lo, but many positive correlations were found with the lentic habitats of the river valley: riv le, flo le and hel $(p<0.05$; $k\{0.19 ;-0.74\}$ ). Particularly clear preferences of individual species were found for hel, where the correlation coefficients were relatively high. Most species showed a significant correlation with helocrenes (Tab. 3). In terms of ecological preferences, the species listed in the table can be classified as those characteristic of springs; those preferring small, boggy, often temporary water bodies; and eurytopic species. Species that were significantly positively correlated with standing water bodies in the floodplain were mainly represented by fauna characteristic of small, temporary or permanent water bodies and by eurytopic species (Tab. 3).

When the water level was very high in May, the densities were greater in the habitats of the river channel than they were in the water bodies of the floodplain. The reverse was observed in August, when the water was very low, and in October, when the water level had risen somewhat (Tab. 1). The percentage of individual species in different habitat types can be seen in Table 3.

The waters of riv lo were characterized by high values for oxygen, $\mathrm{pH}$ and $\mathrm{BOD}_{5}$, and low values for phosphates and iron, while the reverse pattern was noted for flo le and hel (Tab. 4). In addition, the hel waters were low in nitrates and the flo le waters had high turbidity levels. Temperature, conductivity, hardness, and ammonia content were not significantly correlated with any habitat types. The riv le habitats were also not found to be significantly correlated with any of the chemical variables.

CCA showed that the chemical and physical variables of the water were responsible for $28.7 \%$ of the total variance in the ostracod assemblages in the Krapiel valley. The stepwise selection of environmental variables in multiple canonical analyses showed that $\mathrm{NO}_{3}$ was responsible for $6.8 \%$ of the variance in the ostracod assemblages, $\mathrm{PO}_{3}$ for $4.3 \%$, conductivity for $3.5 \%$, and the remaining statistically significant environmental variables, i.e. $\mathrm{O}_{2}, \mathrm{NH}_{4}$, hardness and $\mathrm{pH}$, for about $2 \%$ each. Area 1 in the CCA diagram (Fig. 3) indicates the species related to a low $\mathrm{NO}_{3}$ value in the water, area 2 the species related to high values of hardness and conductivity, area 3 the species related to high values of $\mathrm{NH}_{4}$ and $\mathrm{NO}_{3}$ content, and area 4 those species related to high values of $\mathrm{O}_{2}$ content and $\mathrm{pH}$.

The water of riv lo had the highest flow velocity and the greatest proportion of mineral matter in the sediments, while flo le and hel had the lowest flow velocity and the greatest proportion of organic matter in the sediments (Tab. 5). The mean grain size in the various habitat types is indicative of medium-grained sand (M) and poorly sorted sediments (W). The riv le and flo le habitats had the greatest degree of plant cover.

CCA showed that the biotic and abiotic environmental factors associated with substrate type were responsible for $23 \%$ of the total variance in the ostracod assemblages in the valley of the Krapiel. The stepwise selection of environmental variables in multiple canonical analyses showed that the W coefficient (sediment sorting) was responsible for $6.8 \%$ of the variance in the ostracod assemblages, plants for $4.2 \%$, insolation for $5.2 \%$, the $\mathrm{M}$ index (mean grain size) for $2.7 \%$, and the proportion of mineral matter for $1.7 \%$. Area 1 in the CCA diagram (Fig. 4) indicates species strongly related to the high proportion of organic matter in the substrate and with insolation, area 2 highlights species strongly related to the high value of the $M$ index, area 3 shows species strongly related to the presence of plants, and area 4 indicates species strongly related to the high value of the $\mathrm{W}$ coefficient.

Based on the ostracod species composition at individual sampling sites in the main channel of the Krapiel, 5 stretches of the river were distinguished (Fig. 5), within which the sites had certain common features. Group 1 consists of sites where the river is wide and deep, with a slow current and fine-grained sediments, and often with accumulated mud. Group 2 covers 
A. Szlauer-Łukaszewska and V. Pešić: Knowl. Manag. Aquat. Ecosyst. 2020, 421, 23

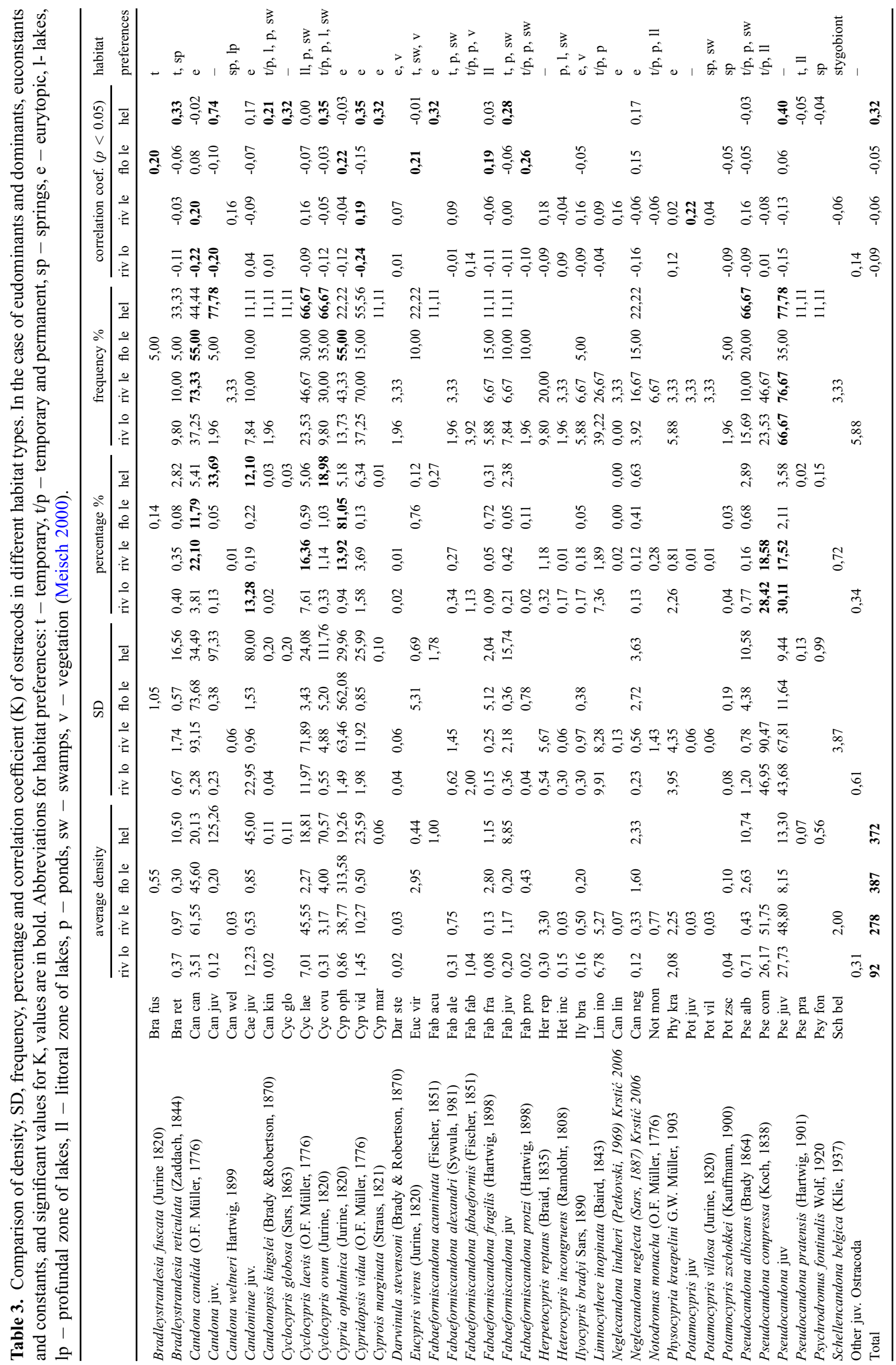


Table 4. Average chemical and physical variables of water in different habitat types. Significant positive correlations according to Spearman's rank correlation $(p<0.05)$ are in bold, and negative correlations are underlined.

\begin{tabular}{|c|c|c|c|c|}
\hline & riv lo & riv le & flo le & hel \\
\hline $\mathrm{O} 2 \mathrm{mg} \mathrm{L}^{-1}$ & 7,8 & 7,4 & $\underline{4,4}$ & 5,1 \\
\hline$S D$ & 2,0 & 2,0 & 3,1 & 1,9 \\
\hline $\mathrm{pH}$ & 7,4 & 7,2 & 6,4 & 6,7 \\
\hline$S D$ & 0,8 & 0,7 & 1,2 & 1,5 \\
\hline temp. ${ }^{\circ} \mathrm{C}$ & 14,4 & 14,8 & 14,0 & 15,5 \\
\hline$S D$ & 2,8 & 2,8 & 3,2 & 2,4 \\
\hline Conductivity $\mu \mathrm{S} \mathrm{cm}-1$ & 200 & 197 & 195 & 190 \\
\hline$S D$ & 54 & 53 & 87 & 101 \\
\hline NH4 mg L ${ }^{-1}$ & 0,78 & 0,91 & 1,04 & 0,80 \\
\hline$S D$ & 0,56 & 0,70 & 0,74 & 0,36 \\
\hline $\mathrm{NO}_{3} \mathrm{mg} \mathrm{L}^{-1}$ & 1,60 & 1,58 & 1,09 & $\underline{0,53}$ \\
\hline$S D$ & 1,05 & 1,00 & 0,67 & $\overline{0,29}$ \\
\hline $\mathrm{PO}_{3} \mathrm{mg} \mathrm{L}^{-1}$ & 0,34 & 0,37 & 0,63 & 0,67 \\
\hline$S D$ & 0,23 & 0,24 & 0,61 & 0,26 \\
\hline $\mathrm{Fe} \mathrm{mg} \mathrm{L}{ }^{-1}$ & 0,05 & 0,06 & $\mathbf{0 , 1 1}$ & $\mathbf{0 , 1 3}$ \\
\hline$S D$ & 0,05 & 0,06 & 0,13 & 0,07 \\
\hline Turbidity $\mathrm{mg} \mathrm{L}^{-1}$ & 21,2 & 22,2 & 44,8 & 13,0 \\
\hline$S D$ & 43,0 & 52,9 & 65,1 & 12,2 \\
\hline Hardness $\mathrm{mg} \mathrm{L}^{-1}$ & 176 & 161 & 148 & 158 \\
\hline$S D$ & 75 & 68 & 76 & 73 \\
\hline BOD5 mg L ${ }^{-1}$ & 5,33 & 5,19 & $\underline{3,71}$ & 2,98 \\
\hline$S D$ & 1,62 & 1,55 & 2,70 & 1,04 \\
\hline
\end{tabular}

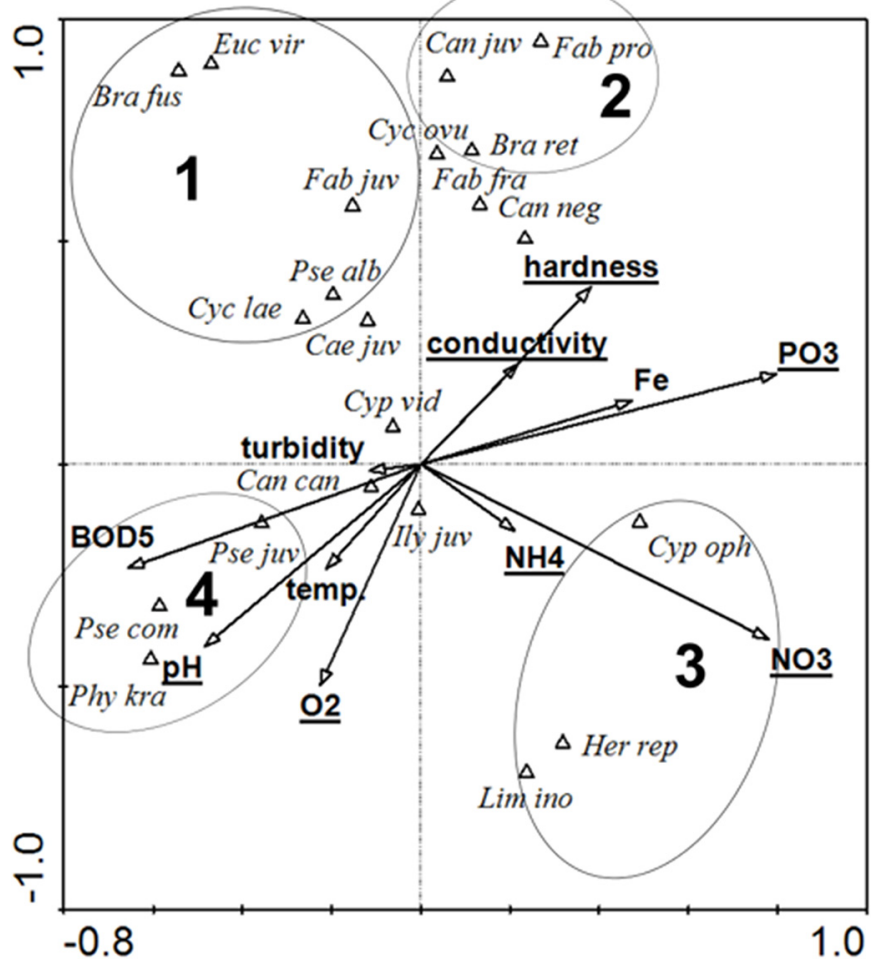

Fig. 3. Ordination diagram for ostracod species and physical and chemical water properties on the first two CCA axes for samples from the Krapiel valley. For explanations of species abbreviations see Table 3. Statistically significant environmental variables are underlined.

Table 5. Substrate variables and other factors directly affecting the substrate in different habitat types. Significant positive correlations according to Spearman's rank correlation $(p<0.05)$ are in bold, and negative correlations are underlined. M - mean sediment grain size, W sorting coefficient.

\begin{tabular}{|c|c|c|c|c|c|c|c|}
\hline & velocity $\mathrm{m} \mathrm{s}^{-1}$ & mineral \% & organic $\%$ & M & W & insolation $\%$ & plants cover \\
\hline riv lo & 0.274 & 91 & $\underline{9}$ & 1.198 & 1.349 & 59 & 1.3 \\
\hline riv le & 0.020 & 88 & 12 & 1.496 & 1.527 & 64 & 2.2 \\
\hline flo le & $\overline{0.002}$ & $\underline{61}$ & 39 & 1.029 & 1.390 & 69 & 2.5 \\
\hline hel & $\overline{0}$ & $\overline{66}$ & 34 & 1.168 & 1.723 & 19 & 1.4 \\
\hline
\end{tabular}

the middle stretch, where the river is fast, with a bottom of gravel and sand and marginal pools with sand and mud. Group 3 comprises stretches of the river situated past the outflow from the lake, characterized by the high content of organic matter in the sediments and marginal pools with plants. Group 4 consists of sites from the lower gorge, with a fast current and a bottom of stones and gravel. Group 5 covers the upper course of the river, with a fast flow and a narrow channel. Group 1 in the dendrogram consists of sites with large standing water bodies in their catchment, where water can be exchanged with the main channel when the water is high. Cyclocypris laevis is dominant in this group; this is a eurytopic species, but it attains its greatest densities in standing water bodies. Its average density in the main river channel is 150 indiv. $\mathrm{m}^{-2}$. In group 2, which has no water bodies in the catchment, juvenile Pseudocandona sp. accounted for the largest proportion of the fauna. These individuals were most likely of the species $P$. compressa, as only this species was abundant in the river channel. Its dominance in this stretch indicates that it is able to develop well in the river channel itself. The second dominant in this stretch, Cypria ophtalmica, had the density characteristic of the waters of the river channel. Group 3 is a segment fed by eutrophic oxbow lakes and thus rich in organic matter, with a dominance of Pseudocandona compressa, with the greatest density recorded here, 419 indiv. $\mathrm{m}^{-2}$. Group 4 has no water bodies in the catchment and a very high proportion of Limnocythere inopinata, which may indicate that it is a species that develops in the river channel itself, i.e. a river species that prefers a mineral substrate. The lack of replenishment from the floodplain may explain why the total density was lowest here, at 20 indiv. $\mathrm{m}^{-2}$. Group 5 is characterized by the dominance of Cypria ophtalmica and density at a similar level as in the water 


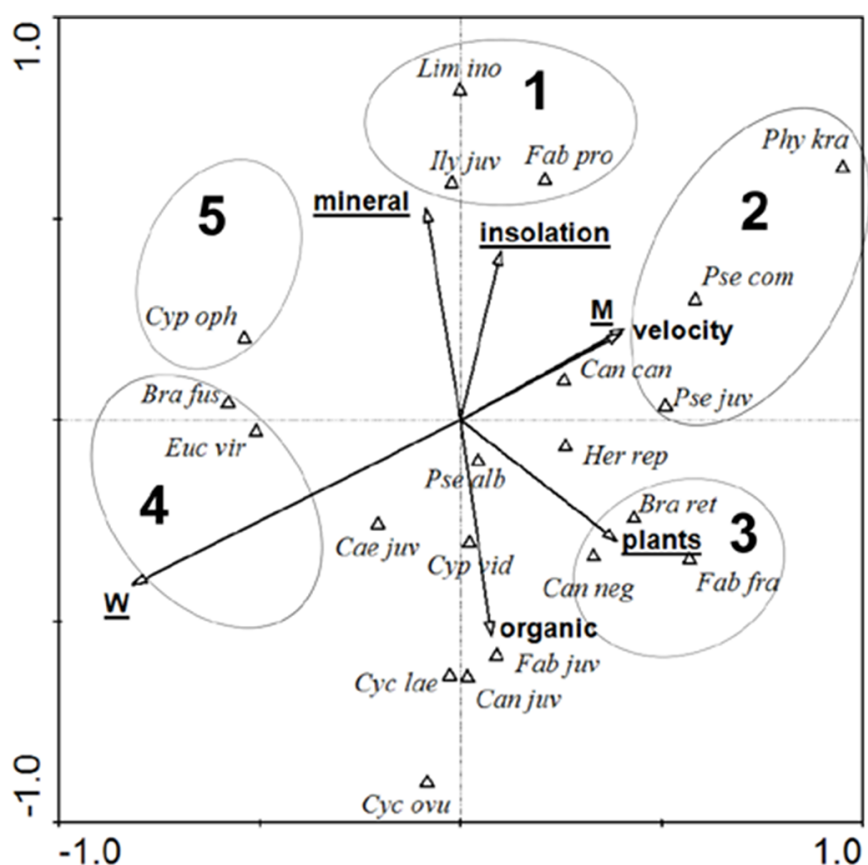

Fig. 4. Ordination diagram for ostracod species and biotic and abiotic environmental factors associated with substrate type on the first two CCA axes for samples from the Krapiel valley. For explanations of species abbreviations see Table 3. Statistically significant environmental variables are underlined.

bodies of the floodplain, at 300 indiv. $\mathrm{m}^{-2}$, which indicates the substantial role of surface water bodies feeding this initial stretch of the river.

\section{Discussion}

In the water bodies of the Krapiel valley and in its main channel, 33 ostracod species were recorded. The checklist of ostracods of Poland, including groundwater and brackish waters, contains 140 species (Namiotko, 2008). Studies on other floodplains of European rivers have recorded 41 species in the Rhine (Scharf, 1988), 42 in the Pripyat (Nagorkaya and de Jonge, 2002), and 15 in the Danube (Kiss and Schöll 2009). Species richness in the main channels comprises 30 species in three rivers of the Iberian Peninsula (Mezquita et al., 1999a), 17 in a heavily polluted river in Spain (Mezquita et al., 1999b), 31 in the lower Oder (Szlauer-Łukaszewska, 2013), and 47 in a stretch of the Oder with groyne fields (Szlauer-Łukaszewska, 2015 b). These data are mainly from large lowland rivers; there are no data on the ostracods occurring in small rivers like the Krapiel, where the impact of the floodplain may be greater than in large rivers, because the river channel itself has fewer lentic areas, which are beneficial for the development of ostracods.

\subsection{Habitat types}

The environmental gradient most often studied in the context of rivers is the longitudinal gradient of the main channel, from the headwaters, through the lower reaches of the river, to the mouth (Rice et al., 2001). The spatial distribution

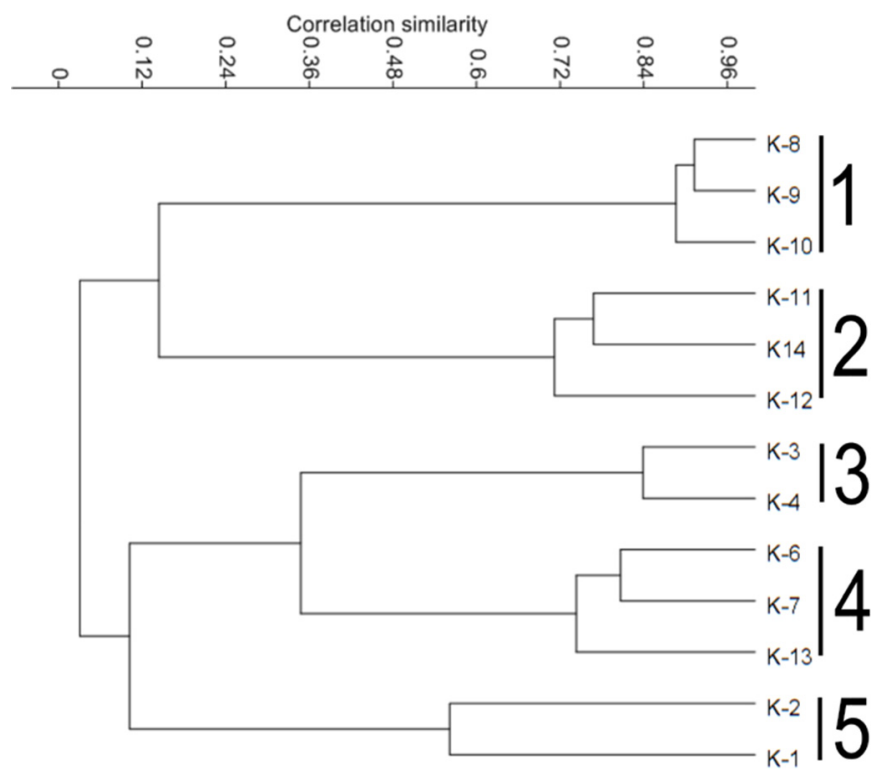

Fig. 5. Similarity dendrogram for sampling sites based on ostracod density (Unweighted Pair Group Method with Arithmetic Mean UPGMA, using correlation similarity).

of the benthos then depends mainly on the hydraulic and sedimentary conditions (Rempel et al., 2000). In the case of the Krapiel, the gradient indeed depends on the hydraulic and sedimentary conditions, but successive segments of the river do not follow one another, beginning with the coarsest sediment and the fastest current and ending with the finest sediment and the slowest current. Such a sequence is violated by the gorge in the lower course of the river (Group 4, Fig. 5). The grouping of individual segments is also significantly influenced by the character of the floodplain and the water bodies feeding each given segment of the river.

Habitat type is one of the most important environmental parameters affecting ostracod assemblages (Marmonier et al., 1994; Külköylüoğlu, 2004; Nagorskaya and Keyser, 2005; Szlauer-Łukaszewska, 2015a), something that our research has also proved. Habitat type in river valleys is associated with the specific location in the river valley and connectivity with the main river channel. According to Kiss et al. (2014), the most important factors influencing the species richness, density, and diversity patterns of the assemblages were the occurrence of flow, connectivity with the main arm, and hydrological distance from the main arm. da Conceição et al. (2017), who investigated variability in ostracod communities in connected and isolated tropical floodplain lakes, were of a similar opinion. It is interesting that the number of species is greatest in the main channel of the Krapiel, at 26, in comparison with the other habitats of the floodplain (Tab. 2). Similar observations were made by Higuti et al. (2009) in the tropical Brazilian River Parana, as well as by Stryjecki et al. (2016) in the Krapiel, in the case of water mites. By contrast, the pattern was reversed in a study of the Danube valley by Kiss and Schöll (2009), but in that case there may have been an intensive growth in the ostracod population in the river channel itself, while the water bodies of the floodplain offered greater species richness. Over most of its course, the main channel of the 
Krapiel does not provide favourable conditions for ostracod development, due to its fast current and very narrow marginal pools areas; the mean current velocity in the lotic zone of the main channel is $0.274 \mathrm{~m} \mathrm{~s}^{-1}$ (with a maximum of 1.034 ), and the mean content of organic matter in the sediment is only $8 \%$ (with a minimum of $0.22 \%$ ) (Tab. 5). The high number of species here can be explained by the fact that the main river channel is periodically the recipient of waters from the entire floodplain, including from water bodies isolated from the main channel when the water level is low or moderate. Evidence of this is shown in the occurrence of species typical of temporary water bodies ( 8 species), springs (4), underground waters (1 species), small water bodies (8), and swamps (7), although these species never attained a high density and their frequency was low (Tab. 3). Pseudocandona compressa, which is dominant in the main river channel and absent from the water bodies of the floodplain, seems to be a typical river species, which is capable of developing in the main channel. When we consider the averages for the entire study period, the juvenile Pseudocandona sp., Candona candida and Cyclocypris laevis that were dominant in the river channel will account for a much lower proportion of the fauna in the water bodies of the floodplain, which also indicates the preference of these taxa for flowing water. CCA analysis identifies the following as river taxa: P. compressa, juvenile Pseudocandona sp., Limnocythere inopinata, Physocypria kraepelini, Herpetocypris reptans, juvenile Ilyocypris sp., and C. laevis. This is partly confirmed by studies in the Oder (Szlauer-Łukaszewska, 2015a; b), where $L$. inopinata and $P$. kraepelini were dominants. Mezquita et al. (2005) indicate L. inopinata, Ilyocypris bradyi, and $H$. reptans as species preferring medium-high water flows. By contrast, Cypria ophtalmica has a $14 \%$ share of the density in the main river channel and as much as $81 \%$ in the water bodies of the floodplain, which indicates that standing water creates better conditions for the development for this species (as in Nagorskaya and de Jonge, 2002). However, it is flexible enough that it can reach very high densities even in a river with a strong current. Mezquita et al. (2005) classify Cypria ophtalmica as a species preferring low water flows.

\subsection{The physical and chemical properties of the water}

The chemical and physical variables of the water are clearly among the most important environmental parameters affecting the ostracod assemblages, as has been demonstrated by numerous publications (Mezquita et al., 2005; Külköylüoğlu and Sari, 2012; Szlauer-Łukaszewska, 2015b; Conceição et al., 2017; and many others). The results of the CCA analysis showed that those variables were responsible for $28.7 \%$ of the total variance in the ostracod assemblages in the Krappiel valley, with nitrates, phosphates, and conductivity most strongly affecting the ostracod assemblages. According to various authors, ostracod assemblages are most influenced by temperature, $\mathrm{pH}$, conductivity, and oxygen (Külköylüoğlu and Sari, 2012); oxygen and water flow (Mezquita et al., 2005); temperature, oxygen and nitrates (Szlauer-Łukaszewska, 2015b); oxygen and pH (Conceição et al., 2017); and COD, phosphates and inorganic nitron ions (Mazzini et al., 2014). The impact of individual parameters on particular species varies. Our results show that the occurrence of Cypria ophtalmica is related to a high content of nutrients $\left(\mathrm{NO}_{3}\right.$ and
$\mathrm{PO}_{3}$ ), while that of Physocypria kraepelini and Pseudocandona compressa is associated with a low nutrient content, higher $\mathrm{pH}$ and better oxygenation, while avoiding waters with high conductivity and $\mathrm{PO}_{3}$. Other dominants, such as Cyclocypris laevis and Candona candida, do not show clear preferences in relation to these environmental parameters. A comparative analysis with the findings of other authors reveals quite different relationships (Mezquita et al., 2005; Külköylüoğlu and Sari, 2012; Szlauer-Łukaszewska, $2015 b)$. It seems that the relationships obtained by various authors are strongly determined by the type of environment studied and by the species that are characteristic of a given geographic region, rather than by individual physical and chemical parameters. This type of data cannot be compared with the results obtained from different areas and habitat types.

\subsection{Features of the microhabitats}

Environmental factors associated with the substrate type were responsible for $23 \%$ of the total variance in the ostracod assemblages in the valley of the Krapiel (CCA analyses). In the case of the ostracods in the Oder, the substrate was responsible for 5.69\% (Szlauer-Łukaszewska, 2015b), in the River Parana $11 \%$ (Higuti et al., 2010), and in Lake Świdwie 20\% (Szlauer-Łukaszewska, 2012). Other authors have also described the ostracod assemblages that are characteristic of different substrate types (Kamiya, 1988; Benzie, 1989; Szlauer-Łukaszewska, 2012, 2013, 2015b; Mazzini et al., 2014). In our study, Limnocythere inopinata, Ilyocypris bradyi and Fabaeformiscandona protzi were associated with a mineral substrate, while vegetation habitats were typical for Cypridopsis vidua, Herpetocypris reptans, Fabaeformiscandona fragilis, Bradleystransesia reticulata, Neglecandona neglecta, Cyclocypris laevis and C. ovum. Physocypria kraepelini, and Pseudocandona compressa preferred a larger grain size and a stronger current (as shown by CCA analysis). The relationship between vegetation and $C$. vidua is widely known (Benzie, 1989; Meisch, 2000; Frenzel et al., 2010; Szlauer-Łukaszewska, 2012, 2015b, Mazzini et al., 2014), as in the case of Herpetocypris reptans (Benzie, 1989; Meisch, 2000; Frenzel et al., 2010; Szlauer-Łukaszewska, 2015b). The occurrence of $B$. reticulata in phytal substrates has been reported by Szlauer-Łukaszewska (2013, 2015b), N. neglecta by Szlauer-Łukaszewska (2012, 2015b), C. leavis and C. ovum by Frenzel et al. (2010); Szlauer-Łukaszewska (2013, 2015b), and F. fragilis by Frenzel et al. (2010); Szlauer-Łukaszewska (2013). L. inopinata prefers a mineral substrate (sand or gravel), as confirmed by Benzie (1989); Nagorskaya and de Jonge (2002); Scharf and Brunke (2013); SzlauerŁukaszewska $(2013,2015 b)$. The same has been found for I. bradyi (Szlauer-Łukaszewska, 2015b) and F. protzi (SzlauerŁukaszewska, 2013).

\subsection{Seasonal variability and the supply of the main channel from the floodplain}

The occurrence of ostracods in the main channel may depend on the character of the floodplain and the water bodies feeding any given segment of the river. Following the occurrence of species at different times of the year with different water levels leads to the same conclusions regarding 
the genesis of ostracod fauna in the main river channel. After flooding in April, water from the floodplain returned in May to the main river channel. Nevertheless, in all the water bodies of the floodplain, different taxa were dominant than in the river channel. In many cases this tendency persisted into August, when the water level was very low, the exchange of water was substantially limited, and nearly all of the helocrenes feeding the river had dried up, and was even seen in October, when the water level had risen somewhat but the helocrenes were still dried up. Note that in May the habitats of the river channel had a much greater ostracod density than the water bodies of the floodplain, and that the situation was reversed in August and October. Thus, the floodplain is as a refugium supplying the river (Sedell et al., 1990). The various ostracod taxa that entered the river from other water bodies were quickly selected by the current in terms of tolerance to this factor, and thus the taxonomic composition of the river channel was different from that of the water bodies. The densities in the water bodies were low in May because the fauna had to be regenerated after the spring flood. Densities in floodplain water bodies can be very significant, reaching as much as an average of 1300 indiv. $\mathrm{m}^{-2}$ (with a maximum of 5568 indiv. $\mathrm{m}^{-2}$ ). The number of individuals can increase not only due to reproduction, but also to the decrease in the area of the water body and the concentration of fauna in a smaller amount of water. The low densities in the river channel in the summer and autumn were probably due to the ostracods being eaten by young fish (Neale, 1964), a lack of or limited numbers of individuals from the water bodies of the floodplain, and the small area of the marginal pools in which the ostracods could reproduce and develop. During floods, water bodies with distinct hydrological characteristics tend to become joined and as a consequence, ecological processes and biological communities tend to be more similar among the distinct habitats that comprise a riverfloodplain system (Thomaz et al., 2007). The supply of the main river channel with floodplain fauna has also been observed in the Krapiel in the case of water mites (Zawal et al., 2017), caddisflies (Buczyńska et al., 2016a), and molluscs (Zawal et al., 2016a), and in the Oder in the case of ostracods (Szlauer-Łukaszewska, 2013). The reverse effect, i.e. the fauna of the Krapiel feeding its floodplain, has been reported for caddisflies (Buczyńska et al., 2016b), water beetles (Pakulnicka et al., 2016a, 2016b), and water mites (Stryjecki et al., 2016; Zawal et al., 2018).

\section{Conclusions}

1. Significant differences were found in terms of the number of taxa, the mean density, and the evenness index of the ostracod assemblages from the lotic habitat of the main river channel, the lentic habitat of the main river channel, the helocrenes, and the other lentic waterbodies of the floodplain.

2. CCA analyses showed that habitat types were responsible for $17 \%$ of the total variance in the ostracod assemblages, while the chemical and physical variables of the water explained $29 \%$, and factors associated with substrate type were responsible for $23 \%$.

3. Among the factors associated with the substrate, sediment sorting, plant coverage and insolation were the most important in determining the composition of the ostracod assemblages.

4. There are few ostracod species capable of developing in the main river channel: Pseudocandona compressa, Cypria ophtalmica, Limnocythere inopinata and Physocypria kraepelini. Other species occurring in this habitat should be considered eurytopic, capable of development in both lentic and lotic habitats, or assumed to have been supplied from the waterbodies of the floodplain.

5. Species characteristic of the lentic environments of the floodplain and the helocrenes include Bradleystrandesia fuscata, Eucypris virens, Cyclocypris globosa, Cyprois marginata, Fabaeformiscandona acuminata, Pseudocandona pratensis and Psychrodromus fontinalis.

6. The abundance and diversity of ostracod fauna in the water bodies of the floodplains is mainly determined by the hydrobiological characteristics of the water bodies and the rate of reproduction of the ostracods living in them. The inflow of individuals from outside the water bodies is not as significant as it is in the case of the river channel.

Acknowledgements. The research was financed by grant no. N 305222537 from the Polish Ministry of Science and Higher Education.

\section{References}

Benzie JA. 1989. The distribution and habitat preference of ostracods (Crustacea: Ostracoda) in a coastal sand-dune lake, Loch of Strathbeg, north-east Scotland. Freshwater Biol 22: 309-321.

Buczyńska E, Buczyński P, Zawal A, Stępień E. 2016a. Environmental factors affecting micro-distribution of larval caddisflies (Trichoptera) in a small lowland reservoir under different types of watershed usage. Fund Appl Limnol 188: 157-170.

Buczyńska E, Czachorowski S, Buczyński P, et al. $2016 \mathrm{~b}$. Environmental heterogeneity at different scales: key factors affecting caddisfly larvae assemblages in standing waters within a lowland river catchment. J Limnol 76: 305-325.

Creuzé des Châtelliers M, Marmonier P. 1993. Ecology of benthic and interstitial ostracods of the Rhône River, France. J Crustacean Biol 13: 268-279.

da Conceição EDO, Higuti J, Martens K. 2017. Variability in ostracod communities (Crustacea, Ostracoda) in connected and isolated tropical floodplain lakes. Ann Limnol-Int J Lim 53: 325-332.

Frenzel P, Keyser D, Viehberg FA, 2010. An illustrated key and (palaeo) ecological primer for Postglacial to Recent Ostracoda (Crustacea) of the Baltic Sea. Boreas 39: 567-575.

Hammer Ø, Harper DAT, Ryan PD. 2001. PAST: Paleontological Statistics Software Package for Education and Data Analysis. Palaeontologia Electronica. Available from: http://palaeo-electron ica.org/2001_1/past/issue1_01.htm

Higuti J, Declerck SA, Lansac-Tôha FA, Velho LFM, Martens K. 2010. Variation in ostracod (Crustacea, Ostracoda) communities in the alluvial valley of the upper Paraná River (Brazil) in relation to substrate. Hydrobiologia 644: 261-278.

Higuti J, Lansac-Tôha FA, Velho LFM, Martens K. 2009. Biodiversity of non-marine ostracods (Crustacea, Ostracoda) in the alluvial valley of the upper Paraná River, Brazil. Braz J Biol 69: 661-668.

Jongman RH, ter Braak CJF, van Tongeren OFR. 1987. Data analysis in community and landscape ecology. Pudoc, Wageningen. 
Kamiya T. 1988. Morphological and ethological adaptations of Ostracoda to microhabitats in Zostera beds. Dev Palaeontology Stratigraphy 11: 303-318.

Kiss A. 2006. Cladocera, Ostracoda and Copepoda assemblages in different side-arms of the Danube in Gemenc floodplain (DanubeDráva National Park, Hungary). Limnological Rep 36: 250-254.

Kiss A, Schöll K. 2009. Checklist of the Crustacea (Cladocera, Ostracoda, Copepoda) fauna in the active floodplain area of the Danube (1843-1806, 1669 and 1437-1489 rkm). Opuscula Zool Budapest 40: 27-39.

Kiss A, Ágoston-Szabó E, Dinka M, Schöll K, Berczik Á. 2014. Microcrustacean (Cladocera, Copepoda, Ostracoda) diversity in three side arms in the Gemenc Floodplain (Danube River, Hungary) in different hydrological situations. Acta Zool Bulg (Suppl.) 7: 135-141.

Külköylüoğlu O. 2004. On the usage of ostracods (Crustacea) as bioindicator species in different aquatic habitats in the Bolu region, Turkey. Ecol Indic 4: 139-147.

Külköylüoğlu O, Sari N. 2012. Ecological characteristics of the freshwater Ostracoda in Bolu Region (Turkey). Hydrobiologia 688: 37-46.

Marmonier P, Creuzé des Châtelliers M. 1992. Biogeography of the benthic and interstitial living ostracods (Crustacea) of the Rhône River (France). J Biogeogr 19: 693-704.

Marmonier P, Bodergat AM, Doledec S. 1994. Theoretical habitat templets, species traits, and species richness: ostracods (Crustacea) in the Upper Rhône River and its floodplain. Freshwater Biol 31: 341-355.

Mazzini I, Ceschin S, Abati S, Gliozzi E, Piccari F, Rossi A. 2014. Ostracod communities associated to aquatic macrophytes in an urban park in Rome, Italy. Int Rev Hydrobiol 99: 425-434.

Meisch C. 2000. Crustacea, Ostracoda. In Schwoerbel J, Zwick P, eds. Süßwasserfauna von Mitteleuropa 8 (3), Spektrum Akademischer Verlag, Heidelberg, Berlin, 522 p.

Mezquita F, Griffiths HI, Sanz S, Soria J M, Piñón A. 1999a. Ecology and distribution of ostracods associated with flowing waters in the eastern Iberian Peninsula. J Crustacean Biol 19: 344-354.

Mezquita F, Hernández R, Rueda J. 1999b. Ecology and distribution of ostracods in a polluted Mediterranean river. Palaeogeogr Palaeoclimatol Palaeoecol 148: 87-103.

Mezquita F, Roca JR, Reed JM, Wansard G. 2005. Quantifying species-environment relationships in non-marine Ostracoda for ecological and palaeoecological studies: examples using Iberian data. Palaeogeogr Palaeoclimatol Palaeoecol 225: 93-117.

Mezquita F, Tapia G, Roca JR. 1999c. Ostracoda from springs on the eastern Iberian Peninsula: ecology, biogeography and palaeolimnological implications. Palaeogeogr Palaeoclimatol Palaeoecol 148: 65-85.

Nagorskaya L, de Jonge J. 2002. Ostracoda (Crustacea) from the lowland floodplain of the river Pripyat. In Escobar-Briones E, Alvarez F, eds. Modern Approaches to the Study of Crustacea, Springer, Boston, 263-273.

Nagorskaya L, Keyser D. 2005. Habitat diversity and ostracod distribution patterns in Belarus. Hydrobiologia 538: 167-178.

Namiotko T. 2008. Małżoraczki (Ostracoda). Fauna of PolandCharacteristics and checklist of species. Polish Acad Sci 3: 315-326.

Neale JW. 1964. Some factors influencing the distribution of Recent British Ostracoda. Pubblicazioni della Stazione Zoologica di Napoli 33: 247-307.
Pakulnicka J, Buczyński P, Dąbkowski P, et al. 2016a. Development of fauna of water beetles (Coleoptera) in waters bodies of a river valley-habitat factors, landscape and geomorphology. Knowl Manag Aquat Ecol 417: 40.

Pakulnicka J, Buczyński P, Dąbkowski P, et al. 2016b. Aquatic beetles (Coleoptera) in springs of a small lowland river: habitat factors vs. landscape factors. Knowl Manag Aquat Ecol 417: 29.

Rempel LL, Richardson JS, Healey MC. 2000. Macroinvertebrate community structure along gradients of hydraulic and sedimentary conditions in a large gravel-bed river. Freshwater Biol 45: $57-73$.

Rice SP, Greenwood MT, Joyce CB. 2001. Tributaries, sediment sources, and the longitudinal organisation of macroinvertebrate fauna along river systems. Can J Fish Aquat Sci 58: 824-840.

Roca JR, Baltanás A. 1993. Ecology and distribution of Ostracoda in Pyrenean springs. J Crustacean Biol 13: 165-174.

Rosati M, Cantonati M, Primicerio R, Rossetti G. 2014. Biogeography and relevant ecological drivers in spring habitats: a review on ostracods of the Western Palearctic. Int Rev Hydrobiol 99: 409-424.

Scharf B, Brunke M. 2013. The recolonization of the river Elbe with benthic and hyporheic Ostracoda (Crustacea) after the reunion of Germany in 1989. Int Rev Hydrobiol 98: 305-312.

Scharf BW. 1988. Living Ostracods from the Nature Reserve "Hördter Rheinaue" (Germany). In: Hanai T, Ikeya N, Ishizaki K, eds. Dev Palaeontology Stratigraphy 11: 501-517.

Sedell JR, Reeves GH, Hauer FR, Stanford JA, Hawkins CP. 1990. Role of refugia in recovery from disturbances: modern fragmented and disconnected river systems. Envir Manag 14: 711-724.

Sokal RR, Rohlf FG. 1995. Biometry. WH Freeman and Co, New York, $850 \mathrm{p}$.

Stępień E, Zawal A, Buczyńska E, Buczyński P. 2015. Changes in the vegetation of a small lowland river valley (Krapiel, NW Poland) after dredging. Acta Biol 22: 128-153.

Stryjecki R, Zawal A, Stępień E, et al. 2016. Water mites (Acari, Hydrachnidia) of water bodies of the Krapiel River valley: interactions in the spatial arrangement of a river valley. Limnology 17, 247-261.

Szlauer-Łukaszewska A. 2012. Ostracod assemblages in relation to littoral plant communities of a shallow lake (Lake Świdwie, Poland). Int Rev Hydrobiol 97: 262-275.

Szlauer-Łukaszewska A. 2013. Variation of ostracod communities in a lowland river channel as exemplified by the lower course of the Oder (N-W Poland). Int Rev Hydrobiol 98: 313-321.

Szlauer-Łukaszewska A. 2015a. Effects of river bed regulation on habitats and communities: A case study for ostracods in the Oder River, Poland. Int Rev Hydrobiol 99: 1-10.

Szlauer-Łukaszewska A. 2015b. Substrate type as a factor affecting the ostracod assemblages in groyne fields of the Oder River (Poland). North-West J Zool 11: 274-287.

Ter Braak CJF, Šmilauer P. 2002. CANOCO 4. Ithaca, NY, USA: Microcomputer Power.

Ter Braak CJF. 1986. Canonical correspondence analysis: a new eigenvector technique for multivariate direct gradient analysis. Ecology 67: 1167-1179.

Thomaz SM, Bini LM, Bozelli RL. 2007. Floods increase similarity among aquatic habitats in river-floodplain systems. Hydrobiologia 579: $1-13$.

Zawal A, Lewin I, Stępień E, et al. 2016. The influence of the landscape structure within buffer zones, catchment land use and 
A. Szlauer-Łukaszewska and V. Pešić: Knowl. Manag. Aquat. Ecosyst. 2020, 421, 23

instream environmental variables on mollusc communities in a medium-sized lowland river. Ecol Res 31: 853-867.

Zawal A, Stryjecki R, Stępień E, et al. 2017. The influence of environmental factors on water mite assemblages (Acari, Hydrachnidia) in a small lowland river: an analysis at different levels of organization of the environment. Limnology 18: $333-343$
Zawal A, Stryjecki R, Buczyńska E, et al. 2018. Water mites (Acari, Hydrachnidia) of riparian springs in a small lowland river valley: what are the key factors for species distribution? PeerJ 6: e4797. Zhai M, Nováček O, Výravský D, Syrovátka V, Bojková J, Helešic J. 2015. Environmental and spatial control of ostracod assemblages in the Western Carpathian spring fens. Hydrobiologia 745: 225-239.

Cite this article as: Szlauer-Łukaszewska A, Pešić V. 2020. Habitat factors differentiating the occurrence of Ostracoda (Crustacea) in the floodplain of a small lowland River Krąpiel (N-W Poland). Knowl. Manag. Aquat. Ecosyst., 421, 23. 